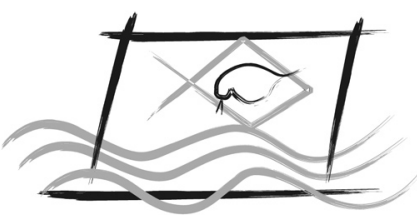

J. Braz. Soc. Ecotoxicol., v. 7, n. 2, 2012, 73-78

doi: $10.5132 / j b s e .2012 .02 .011$

\title{
Localization of inorganic and organic mercury in the liver and kidney of Cyprinus carpio by autometallography
}

\author{
M. Mela ${ }^{1,2}$, F.F. Neto ${ }^{3}$, S.R. Grötzner 3 , I.S. Rabitto ${ }^{3}$; D.F. Ventura ${ }^{1,2} \&$ C. A. Oliveira Ribeiro ${ }^{3}$ \\ ${ }^{1}$ Departamento de Psicologia Experimental, Instituto de Psicologia, Universidade de São Paulo, São Paulo, SP, Brazil. \\ ${ }^{2}$ Núcleo de Apoio à Pesquisa em Neurociência e Comportamento, Universidade de São Paulo, São Paulo, SP, Brazil. \\ ${ }^{3}$ Departamento de Biologia Celular, Universidade Federal do Paraná, Curitiba, PR, Brazil.
}

(Received August 17, 2010; Accept Septemper 29, 2011)

\begin{abstract}
Mercury bioaccumulation in different tissues largely depends upon metal chemical form and has important implications on tissue-specific toxicity. Then, simple tools for mercury tissue localization are very useful for understanding the toxicity of mercurial compounds in fishes. In the present study, inorganic and organic mercury distribution was investigated in carp Cyprinus carpio, utilizing autometallography. Juvenile C. carpio were exposed through force-feeding with mercury contaminated pelleted food at doses of $0.5 \mu \mathrm{g} \mathrm{g}^{-1} \mathrm{of} \mathrm{Hg}^{+2}$ or MeHg twice at 15 days interval, and killed 15 days after the second exposure for sampling. Organic mercury was observed inside hepatocytes and in biliary ducts of liver, whereas inorganic form of mercury was observed only in biliary ducts. In the kidney, mercury was observed mainly in renal tubules, with the predominance of inorganic over organic mercury. The present study demonstrated that autometallography is a useful tool for the tissue localization of two mercurial compounds in the liver and kidney of C. carpio after trophic exposure.
\end{abstract}

Keywords: Autometallography, mercury, liver, kidney, Cyprinus carpio.

\section{Localização do mercúrio inorgânico e orgânico em fígado e rim de Cyprinus carpio através da autometalografia}

\section{Resumo}

A bioacumulação de mercúrio em diferentes tecidos depende da forma química do metal e tem implicações importantes na toxicidade de tecidos específicos. Deste modo, ferramentas simples para a localização de mercúrio em tecidos são úteis para a compreensão da toxicidade de compostos mercuriais em peixes. No presente estudo, a distribuição de mercúrio inorgânico e orgânico foi investigada em carpa Cyprinus carpio, utilizando autometalografia. Exemplares juvenis de C. carpio foram expostos através de alimentação forçada com pellets de ração contaminada com mercúrio em doses de $0.5 \mu \mathrm{g} \mathrm{g}^{-1} \mathrm{Hg}^{+2} \mathrm{ou} \mathrm{MeHg}$ duas vezes em um intervalo de quinze dias, e sacrificados 15 dias após a segunda exposição para amostragem. O mercúrio orgânico foi observado no interior dos hepatócitos e nos ductos biliares. No rim, o mercúrio foi observado principalmente nos túbulos renais, com predominância do mercúrio inorgânico sobre o orgânico. O presente estudo demonstrou que a autometalografia é uma ferramenta útil para a localização tecidual de dois compostos mercuriais em fígado e rim de C. carpio após exposição trófica.

Palavras-chave: Autometalografia, mercúrio, fígado, rim, Cyprinus carpio. 


\section{INTRODUCTION}

Metal contamination of aquatic ecosystems is a serious worldwide environmental problem and mercury $(\mathrm{Hg})$ is among the best-known nonessential toxic metals, occurring in both organic and inorganic forms. However, different mercury compounds have distinct toxicity, tissue bioaccumulation and dose-effect and dose-response relationships (Mason et al., 2002).

Methyl mercury (MeHg) is the main organic form of $\mathrm{Hg}$, produced through methylation of inorganic $\mathrm{Hg}$ by bacteria. $\mathrm{MeHg}$ bioavailability and bioaccumulation usually exceeds that of inorganic mercury (Laporte et al., 2002; Manson, 2002; Oliveira Ribeiro et al., 2002).

Exposure route and chemical form of mercury affect its tissue-specific distribution. Critical target organs of mercury chloride trophic exposure are kidney, liver, blood, intestinal epithelium and lungs (Berlin \& Ulberg, 1987; Nielsen \& Andersen, 1989), whereas liver, nervous system, intestinal epithelium, kidney and muscle are common targets of organic mercury (Möller-Madsen \& Danscher, 1991; Oliveira Ribeiro et al., 2002; Clarkson, 2003; Mela et al., 2007). Although chemical analyses provided information about tissue distribution, the exact cellular localization of mercury has not been available until the introduction of the autometallographic technique (AMG) (Danscher \& Möller-Madsen, 1985; Baatrup \& Danscher, 1987; Stoltenberg \& Danscher, 2000). The AMG is an auto-induced silver amplification method of some metal atoms and metal molecules in biological sections by applying basic principles of photography (Danscher, 1984). Using AMG, metal atoms, metal sulphides or metals selenides can be visualized under the light and the electron microscopes after silver enhancement as black silver deposits (Danscher \& Möller-Madsen, 1985; Mela et al., 2010).

Currently, there are a number of studies describing the distribution of mercury in mammal tissues (Hansen \& Danscher, 1997; Pedersen et al., 1999), but few in fishes (Baatrup \& Danscher, 1987; Mela et al., 2010). Fish are considered good indicators of environmental contamination because they are aquatic organisms that bioaccumulate several classes of pollutants in their tissues from water and food sources. In particular, the common carp C. carpio is an economically important fish spread worldwide in cultures in Asia, Europe and Latin America (Aydın \& Köprücü, 2005) and is easily maintained in laboratory (Gengiz, 2006).

Upon entering cells, mercury can interact with several biomolecules such as glutathione and protein sulphydryl groups present in antioxidant, DNA repair and metal homeostasis proteins, altering their normal physiological activity. Metallothioneins, for example, are low molecular mass, cysteine-rich metal-binding polypeptides that production can be induced by mercury exposure (Nordberg \& Nordberg, 2000; Yoshida et al., 1999) and occur in a large number of evolutionarily diverse organisms, including fishes (George \& Langston, 1994). Metallothioneins have an important role in essential metal homeostasis and in sequestering and detoxication of non-essential metals (Nordberg, 1998), as evidenced by the overexpression of these proteins in the target organs due to metal exposure, including in fish Cyprinus carpio (Ariyoshi et al., 1990).

Data about the toxic mechanisms of mercury and its pharmacokinetics are abundant though still incomplete, and distribution studies based on methods to detect minute mercury traces can help understanding mercury toxicity and provide cues for the diversity of toxic effects reported in the literature. In the present study, AMG was utilized to visualize deposits of mercury in kidney and liver sections of $C$. carpio exposed through feed to mercury chloride or methyl mercury. Metallothionein concentration was also assayed in the liver and kidney of fishes in order to verify whether those doses of inorganic and organic $\mathrm{Hg}$ altered metallothionein levels.

It is the first comprehensive investigation aiming to determine the localization of two forms of mercury with different chemical and toxicological properties in the liver and kidney of C. carpio after trophic exposure.

\section{MATERIAL AND METHODS}

\section{Mercury exposure conditions}

A number of eighteen juvenile Cyprinus carpio (body weight: $92.12 \pm 7.34 \mathrm{~g} \mathrm{w} . w . ;$ standard length: $19.36 \pm 0.48$ $\mathrm{cm}$ ) were randomly placed in three tanks containing $100 \mathrm{~L}$ of dechlorinated tap water and maintained during ten days for acclimation under controlled aeration, temperature (21 \pm $2^{\circ} \mathrm{C}$ ), photoperiod ( $12 \mathrm{~h}$ light: $12 \mathrm{~h}$ dark), pelleted food supply (three times a week) and cleaning procedures (replacement of one-third water volume twice a week). After acclimation, C. carpio were exposed through force-feeding with mercury contaminated pelleted food, one group of fish $(n=6)$ was exposed to $0.5 \mu \mathrm{g} \mathrm{g}^{-1}$ of $\mathrm{Hg}^{+2}$, a second group ( $\left.\mathrm{n}=6\right)$ to 0.5 $\mu \mathrm{g} \mathrm{g}^{-1}$ of $\mathrm{MeHg}$ and a third group $(\mathrm{n}=6)$ was not exposed (control). In all cases exposure was performed twice ( 0 and 15 days) through anesthetized fish $(0.02 \% \mathrm{MS} 222$, ethyl-ester3 -aminobenzoic acid in water) with a solution containing mercury (100-240 $\mu \mathrm{L}$, according to the body mass of the fish) or the vehicle solution $\left(\mathrm{HCl}\right.$ at 0.1 moles $\left.\mathrm{L}^{-1}\right)$. On day thirty, fish were anesthetized and killed by section of spinal cord, and liver and the posterior kidney were collected for subsequent analysis. All procedures were performed according to the NIH Specify guidelines and Federal University of Parana commission for studies involving human or animal subjects (http://www.bio.ufpr.br/ceea/html/index.html).

\section{Autometallography and Light microscopy}

Liver and kidney samples were fixed in fixative solution (3\% glutaraldehyde, $0.1 \mathrm{M}$ sodium cacodylate buffer, $\mathrm{pH} 7.4$ ) for $24 \mathrm{~h}$ at $4{ }^{\circ} \mathrm{C}$ and rinsed in buffer $(0.1 \mathrm{M}$ sodium cacodylate buffer, $2 \% \mathrm{NaCl}, \mathrm{pH}$ 7.4). Then, the samples were dehydrated in graded series of ethanol and embedded in Paraplast Plus resin ${ }^{\circledast}$. Sections of five micrometers were obtained 
in microtome. Then, autometallography was performed according to Danscher \& Møller-Madsen (1985). Prior to the AMG development, all tissue sections were coated with $0.5 \%$ of gelatin solution by dipping the slides in a. The slides, placed in jars located in a $26^{\circ} \mathrm{C}$ warm water bath, were AMG developed for $60 \mathrm{~min}$. The process was stopped by replacing the AMG developer with 5\% sodium thiosulphate solution for $10 \mathrm{~min}$ and the slides were rinsed with tap water at $40^{\circ} \mathrm{C}$ to remove the gelatin. Finally the sections were counterstained with Hematoxylin and Eosin, mounted in Entellan and observed under the Leica ${ }^{\circledR}$ DME light microscope.

\section{Determination of Metallothionein concentration}

Liver and posterior kidney were collected, frozen and maintained at $-76^{\circ} \mathrm{C}$ prior to metallothionein determination. For the assay, samples were homogenized in ice-cold buffer ( $0.5 \mathrm{mM}$ de phenylmethylsulphonylfluoride (PMSF), $0.01 \%$ de $\beta$-mercaptoethanol, $20 \mathrm{mM}$ Tris- $\mathrm{HCl}, 500 \mathrm{mM}$ sucrose, $\mathrm{pH}$ 8.6), and centrifuged at $15000 \mathrm{~g}$ for $40 \mathrm{~min}$ at $0^{\circ} \mathrm{C}$. Then, 300 $\mu \mathrm{L}$ of supernatant (buffer for the blank) and $342 \mu \mathrm{L}$ of ethanolchloroform $\left(13: 1 ;\right.$ at $\left.-20^{\circ} \mathrm{C}\right)$ were mixed and centrifuged at 6000 $g$ for $10 \mathrm{~min}, 0^{\circ} \mathrm{C}$. A volume of $490 \mu \mathrm{L}$ of the new supernatant was mixed with $1502 \mu \mathrm{L}$ of ethanol- $\mathrm{HCl}\left(45: 1\right.$; at $\left.-20^{\circ} \mathrm{C}\right)$ and kept at $-20^{\circ} \mathrm{C}$ during $1 \mathrm{~h}$. After this period, the tubes were centrifuged $\left(6000 \mathrm{~g}\right.$ for $10 \mathrm{~min}$ and $\left.0^{\circ} \mathrm{C}\right)$ and the pelleted proteins were suspended with $50 \mu \mathrm{L}$ of $250 \mathrm{mM} \mathrm{NaCl}$ solution. Next, $50 \mu \mathrm{L}$ of EDTA solution (4 mM EDTA-2Na, $1 \mathrm{M} \mathrm{HCl}$ ) and $1000 \mu \mathrm{L}$ of Ellman solution (2 mM DTNB (5,5'-dithio-bis(2nitrobenzoic acid), $0.2 \mathrm{M}$ sodium phosphate, $2 \mathrm{M} \mathrm{NaCl}$ ) were added to the tubes mixed and centrifuged ( $3000 \mathrm{~g}$ for $5 \mathrm{~min}$ ) for absorbance determination at $412 \mathrm{~nm}$. Sulfhydryl content was determined by comparison to a glutathione (GSH) curve, and metallothionein concentration was calculated considering the metallothionein cysteine content described for mussels of 30\% (Viarengo et al., 1997 with minor modifications).

\section{Chemicals}

Paraplast,MS222(ethyl-ester-3-aminobenzoicacid), gelatin and chloroform were purchase from Sigma-Aldrich (MO, USA). $\beta$-Mercaptoethanol and phenylmethylsulphonylfluoride (PSMF) were from Fluka (MO, USA). Entellan, ethanol, formol, acetic acid, sodium cacodylate and glutaraldehyde were purchased from Merck (North American, S.A.). Hematoxylin, eosin, sodium thiosulphate, sodium phosphate, DTNB (5,5'-dithio-bis(2-nitrobenzoic acid), (EDTA) thylenediamine tetraacetic acid, gum arabic, sodium citrate, hydroquinone and silver lactate were purchased from VETEC (Duque Caxias, RJ, BR). HCL, $\mathrm{NaCl}$, tris- $\mathrm{HCl}$ was obtained from Cristalia Laboratories (SP, BR).

\section{RESULTS}

No mortality, signs of mobility changes and skin lesions were observed in the control and experimental groups throughout the experiment.

\section{Analysis of mercury distribution by autometallography}

Unaltered hepatic parenchyma with groups of hepatocytes delimiting sinusoids, some biliary ducts and the hepatic vein (Figs. 1A and 1a) and none mercury deposits were observed in control fish. Conversely, mercury deposits were observed in cells of hepatic biliary ducts after inorganic mercury exposure (Fig. 1B), and inside hepatocyte cytoplasm and epithelial cells of biliary ducts after organic mercury exposure (Fig. 1C), indicating differences in the liver uptake and elimination of different mercury compounds.
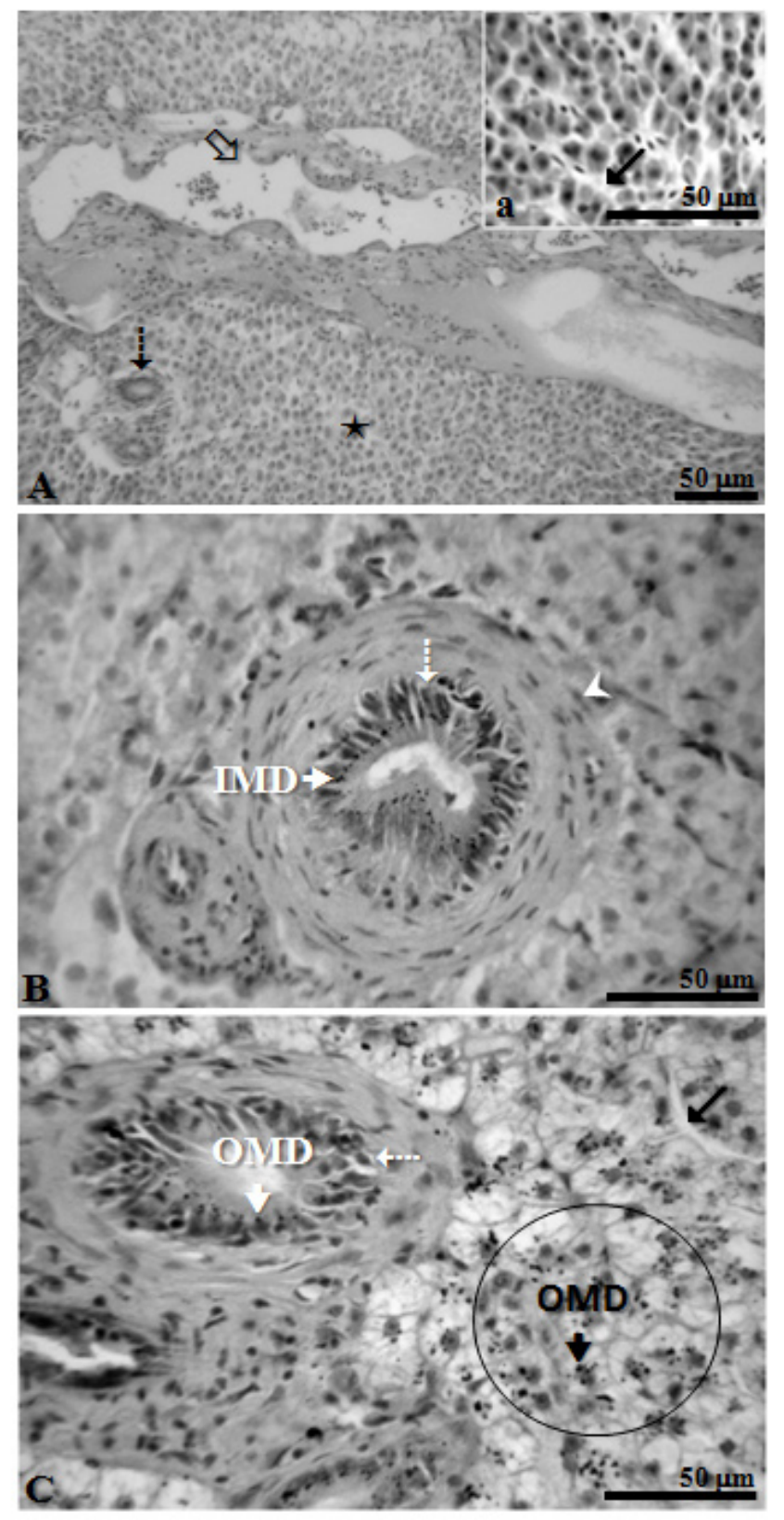

Figure 1 - Autometallography of liver cross-section counterstained with Hematoxylin-eosin. (A) Control group (no mercury was visualized). Hepatic parenchyma $(\star)$ with hepatocytes delimiting sinusoids (see detail in "a" $(\swarrow)$ ), some biliary ducts $(\downarrow)$ and the hepatic vein $(\unlhd)$. (B) Inorganic mercury deposits (IMD - white arrow) on epithelial cells of biliary ducts $(\downarrow)$ surrounded by connective tissue $(<)$. (C) Organic mercury deposits inside hepatocyte cytoplasm (OMD - black arrow) and in epithelial cells (OMD white arrow) of biliary ducts $(\downarrow)$. Sinusoids can be visualized $(\swarrow)$. 
No mercury deposits were observed in the posterior kidney of control fish (Figs. 2A and 2a). Conversely, mercury was visualized mainly in the kidney renal tubules, but not in the glomerulus, with the predominance of inorganic (Fig. 2B) over organic mercury (Fig. 2C) in exposed fish, reflecting kidney preference of inorganic mercury.

\section{Metallothionein in liver and posterior kidney}

Metallothionein protein levels in the liver and posterior kidney were not altered by neither mercurial compounds,
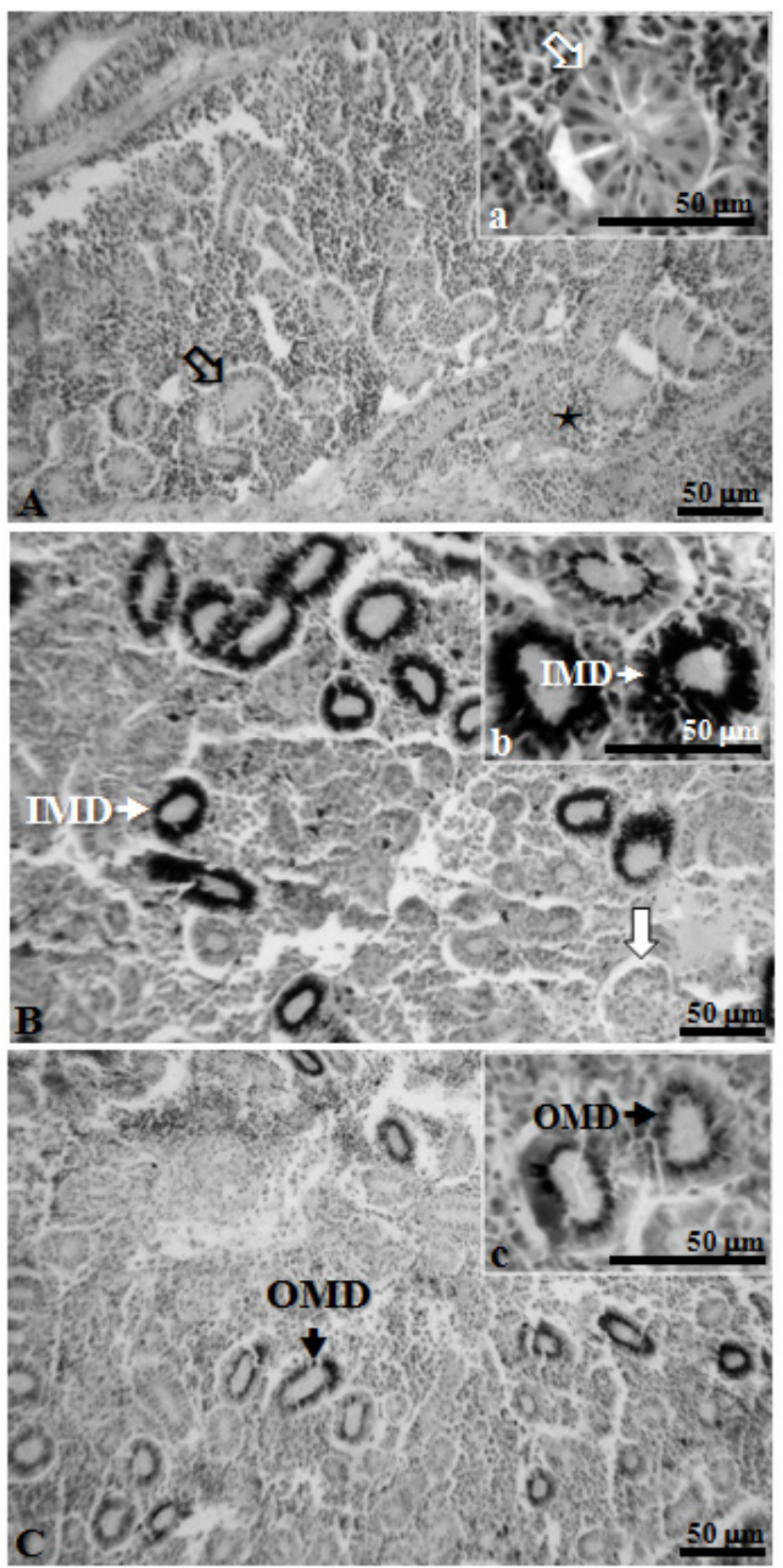

Figure 2 - Autometallography of posterior kidney cross-section counterstained with Hematoxylin-eosin. (A) Control group (no mercury was visualized). Tubules $(§)$ (see also detail in "a") and parenchyma ( $($ ). (B) Inorganic mercury deposits (IMD - white arrow) almost exclusively in the kidney tubules (see detail in "b"), but not in the glomerulus ( ). (C) Organic mercury deposits in kidney tubules (OMD - black arrow) (see detail in "c"). even though literature reports the inducing ability of mercury. Metallothionein levels (mean $\pm \mathrm{SD}$ ) was about $17.7 \pm 6.3 \mu \mathrm{g}$ per $\mathrm{mg}$ of proteins in the liver, whereas in posterior kidney metallothionein levels were about 2.5 times lower $(7.2 \pm 5.6$ $\mu \mathrm{g}$ per mg of proteins) (Fig. 3).

\section{DISCUSSION}

Autometallography provided new useful information about intracellular distribution of mercury in liver and kidney cells of C. carpio. Although it is widely used for determining mercury distribution in mammals (Danscher \& Norgaard, 1983; Danscher \& Möller-Madsen, 1985; Villegas et al., 1999), data describing liver and kidney mercury localization in fish are scarce (Madsen \& Hansen, 1980; Baatrup \& Danscher, 1987).

Kidney uptake and accumulation of inorganic mercury are very rapid (Zalups, 1993a) and surpass that of organic mercury (Zalups et al., 1992). Mercury bioaccumulates primarily in the cortex (Zalups, 1993) and in proximal tubules segments of mammal kidneys (Zalups \& Barfuss, 1990; Rodier et al., 1988; Zalups, 1991a,b), mostly in endocytic structures and lysosomes (Hulman \& Enestrom, 1986). Several findings indicate that a significant mercury fraction in the kidneys of methyl mercury exposed animals is in the inorganic form (Omata et al., 1980; Zalups et al., 1992), suggesting that organic mercury can be converted to inorganic mercury (Dunn \& Clarkson, 1980).

Inorganic mercury binds to two GSH, forming GS-Hg-SG complexes, which are enzymatically cleaved in the lumen of the proximal tubule and producing dicysteinyl-Hg complexes (Cys-Hg-Cys), which resemble cystine (Cys-Cys), being absorbed and accumulating in the proximal tubular cells by cystine transporters (Zalups, 2000). This accumulation is responsible for the localization of mercury on proximal tubules of $C$. carpio observed in the current study, particularly for inorganic mercury. Also, mercury-metallothionein conjugates eliminated by the liver can cross the glomerular filtration barrier and so did not accumulated in glomerulus of $C$. carpio.

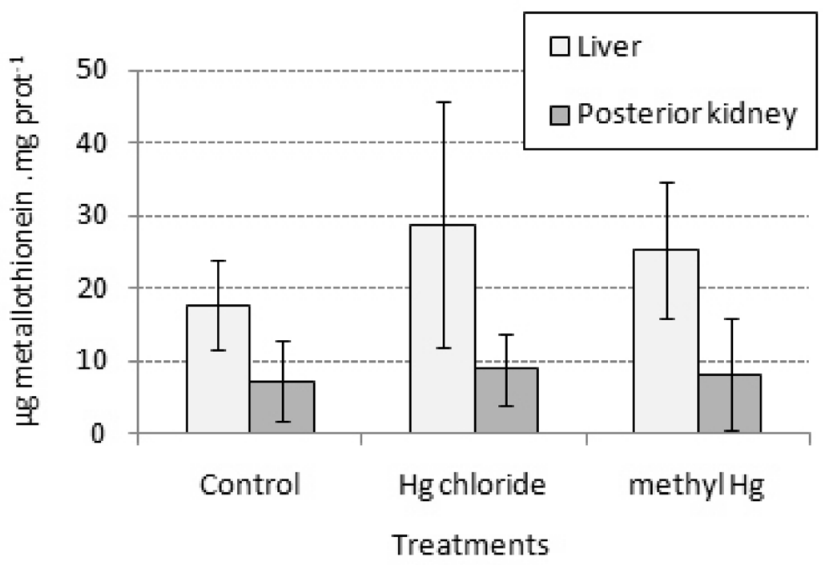

Figure 3 - Metallothionein concentration in liver and kidney of control and exposed fishes to inorganic mercury ( $\mathrm{Hg}$ chloride) and organic mercury (methyl Hg). Mean (columns) \pm standard deviation (SD, bars). 
For methyl mercury exposure, formation of GSH conjugates with or without demethylation (i.e., production of MeHgSG or GS-Hg-SG) might facilitate kidney uptake, although inorganic mercury may still be more available for uptake by kidney in C. carpio.

The liver has key importance in toxicological processes, because it is the primary biotransformation site of many xenobiotics. Methyl mercury can easily cross hepatocyte plasma membrane and binds to thiol groups of glutathione, metallothionein or other molecules with different activities, before being eliminated to the bile or blood stream (Ballatori, 1991). In the first case intestine re-absorption (Norseth \& Clarkson, 1971) can decrease the capacity of the organism to eliminate mercury, whereas in the latter case, kidney may accumulate the metal. Mercury accumulates mainly in apical domain of hepatocytes, facing the bile canaliculi (Loumbourdis \& Danscher, 2004).

After uptake, methylmercury accumulates in hepatocyte lysosomes and can be traced by AMG (Baatrup \& Danscher, 1987). According to Alvarado et al. (2005), lysosomal metal sequestering is considered a general strategy for reducing metal toxicity. Then, methyl mercury deposits in the cytoplasm of liver and kidney cells of C. carpio corroborate data of others authors (Olsson et al., 1998; Baatrup \& Danscher 1987).

Based on metallothionein levels and its physiological roles on metal homeostasis, and on distribution and accumulation in C. carpio it is more likely that the mercury toxic effects after feeding exposure may be worse in kidney than in liver

The AMG method used in the current study is specific and very sensitive (Hörsted-Bindslev et al., 1997), being extremely useful to demonstrate the inorganic and methyl mercury organ-tropism and tissue localization in C. carpio. Furthermore, metallothionein determination was not a good indicator of mercury exposure and bioaccumulation in this species. Finally, methyl mercury and inorganic mercury bioaccumulates preferentially on kidney, whereas hepatocytes bioaccumulates mainly methyl mercury at lowest extent.

\section{ACKNOWLEDEGMENTS}

This work was financial supported by CAPES (Brazilian Agencies for Science and Technology).

\section{REFERENCES}

ALVARADO, N.E., BUXENS, A., MAZON, L.I., MARIGÓMEZ, I. \& SOTO, M., 2005, Cellular biomarkers of exposure and biological effect in hepatocytes of turbot (Scophthalmus maximus) exposed to $\mathrm{Cd} \mathrm{Cu}$ and $\mathrm{Zn}$ and after depuration. Aquat. Toxicol.,74: 110-125.doi:10.1016/j.aquatox.2005.03.024.

ARIYOSHI, T., SHIIBA, S., HASEGAWA, H. \& ARIZONO K., 1990, Profile of metal-binding proteins and heme oxygenase in red carp treated with heavy metals, pesticides and surfactants. Bull. Environ. Contam. Toxicol., 44: 643-649. doi:10.1007/ BF01700889.

AYDIN, R. \& KÖPRÜCÜ, K., 2005, Acute toxicity of diazinon on the common carp (Cyprinus carpio L) embryos and larvae. Pestic. Biochem. Phys., 82: 220-225. doi: 10.1016/j. pestbp.2005.03.001.

BAATRUP, E. \& DANSCHER, G., 1987, Cytochemical demonstration of mercury deposits in trout liver and kidney following methylmercury intoxication. Differentiation of two mercury pools by selenium. Ecotox. Environ. Saf., 14: 129-141.

BALLATORI, N., 1991, Mechanisms of metal transport across liver cell plasma membranes. Drug. Metabol. Rev., 23:83-132.

BERLIN, M \& ULLBERG, G., 1987, Accumulation and retention of mercury in mouse. An autoradiographic study after a single intravenous injection of mercuric chloride. Arch. Environ. Health., 6: 589-601.

CLARKSON, T.W., MAGOS, L. \& MYERS, G.J., 2003, The toxicology of mercury - current exposures and clinical manifestations. N. Engl. J. Med., 349: 1731-1737.

DANSCHER, G. \& NORGAARD, J.O.R.., 1983, Light microscopic visualization of colloidal gold on resin-embedded tissue. $J$. Histochem. Cytochem., 33: 1394-1398.

DANSCHER, G., 1984, Autometallography. A new technique for light and electron microscopic visualization of metals in biological tissues (gold, silver, metal sulphides and metal selenides). Histochemistry., 81: 331-335.

DANSCHER, G. \& MÖLLER-MADSEN, B., 1985, Silver amplification of mercury sulphide and selenide. A histochemical method for light and electron microscopic localization of mercury in tissue. J. Histochem. Cytochem., 33: 219-228.

DUNN, J.D. \& CLARKSON, T.W., 1980, Does mercury exhalation signal demethylation of methylmercury? Health. Phys., 38:411414.

GENGIZ, E.I., 2006, Gill and kidney histopathology in the freshwater fish Cyprinus carpio after acute exposure to deltamethrin. Environ. Toxicol. Pharmacol., 22: 200-204. doi:10.1016/j. etap.2006.03.006.

GEORGE, S.G. \& LANGSTON, W.J., 1994, Metallothionein as an indicator of water quality-assessment of the bioavailability of cadmium, copper, mercury and zinc in aquatic animals at the cellular level. In: Sutcliffe, D.W. (Ed.), Water quality and stress indicators in marine and freshwater ecosystems: linking levels of organization (Individuals, Populations, Communities). The Freshwater Association, Ambleside, pp. 138-153.

HANSEN, J.C.\& DANSCHER, G., 1997, Quantitative and qualitative distribution of mercury in organs from arctic sledgedogs: an atomic absorption spectrophotometric and histochemical study of tissue samples from natural long-termed high dietary organic mercury-exposed dogs from Thule, Greenland. Pharmacol. Toxicol., 77, 189-195.

HORSTED-BINDSLEV, P., DANSCHER, G. \& HANSEN, J.C., 1997, Dentinal and pulpal uptake of mercury from lined and unlined amalgam restoratios in minipigs. Eur. J. Oral. Sci., 105:338-343. doi:10.1111/j.1600.0722.1997.tb00250.x.

HULTMAN, P. \& ENESTROM, S., 1986, Localization of mercury in the kidney during experimental acute tubular necrosis studied by the cytochemical silver amplification method. Br. J. Exp. Pathol., 67:493-503.

LAPORTE, J-M., ANDRES, S. \& MASON, R.P., 2002, Effect of ligands and other metals on the uptake of mercury and methylmercury across the gills and instestine of the blue crab (Callinectes sapinus). Comp. Biochem. Pharmacol. Part C., 131:185-196.

LOUMBOURDIS,N.S.\&DANSCHER,G.,2004,Autometallographic tracing of mercury in frog liver. Environ. Pollut., 129: 299-304. doi:10.1016/j.envpol.2003.10.010.

MADSEN, K.M. \& HANSEN. J.C., 1980, Subcellular distribution of mercury in the rat kidney cortex after exposure to mercuric chloride. Toxicol. Appl. Pharmacol., 54: 443-453.

MASON, R.P., 2002, The bioaccumulation of mercury, 
methylmercury and other toxic elements into pelagic and benthic organisms. Chapter 6. In: Newman, M.C., Roberts, M.H. \& Hale, R.C. (Eds.), Coastal and Estuarine Risk Assessment, Lewis Publ, Boca Raton, pp. 127-149.

MELA, M., RANDI, M.A., VENTURA, D.F., CARVALHO, C.E., PELLETIER E. \& OLIVEIRA RIBEIRO, C.A., 2007, Effects of dietary methylmercury on liver and kidney histology in the neotropical fish Hoplias malabaricus. Ecotoxicol. Environ. Saf., 68: 426-435.doi: 10.1026/j.ecoenv.2006.11.013

MELA, M., CAMBIER, S., MESMER-DUDONS, N., LEGEAY, A., GRÖTZNER, S.R., OLIVEIRA RIBEIRO, C.A., VENTURA, D.F. \& MASSABUAU J-C., 2010, IN PRESS, Methylmercury localization in Danio rerio retina after trophic and subchronic exposure: a basis for neurotoxicology. Neurotoxicology. doi:10.1016/j.neuro.2010.04.009.

MÖLLER-MADSEN, B. \& DANSCHER, G., 1991, Localization of mercury in CNS of the rat. IV. The effect of selenium on orally administered organic and inorganic mercury. Toxicol. Appl. Pharmacol., 108:457-473.

NIELSEN, J.B. \& ANDERSEN, O., 1989, Oral mercuric chloride exposure in mice: effects of dose on intestinal absorption and relative organ distribution. Toxicology., 59: 1-10.

NORDBERG, M., 1998, Metallothioneins: historical review and state of knowledge. Talanta., 46: 243-254.

NORDBERG, M. \& NORDBERG, G., 2000, Toxicological aspects of metallotionein. Cell. Mol. Biol., 46:451-63.

NORSETH, T. \& CLARKSON, T.W., 1971, Intestinal transport of ${ }^{203} \mathrm{Hg}$-labeled methylmercury chloride. Arch. Eniron. Health., 22: 568-577.

OLIVEIRA RIBEIRO, C.A., BELGER, L., PELLETIER, E. \& ROULEAU, C., 2002, Histopathological evidence of inorganic mercury and methyl mercury toxicity in the arctic charr (Salvelinus alpinus). Environ. Res., 90: 217-25.doi:10.1016/ S0013-9351(02)0025-7.

OLSSON, P.E, KLING P. \& HOGSTRAND, C., 1998, Mechanisms of heavy metal accumulation and toxicity in fish. In: Langston, W.J. \& Bebianno, M.J. (Eds), Metal metabolism in aquatic environments, Chapman and Hall, London, pp. 321-350.

OMATA, S., SATO. M., SAKIMURA, K. \& SUGANO, H., 1980, Time-dependent accumulation of inorganic mercury in subcellular fractions of kidney, liver, and brain or rats exposed to methylmercury. Arch. Toxicol., 44:231-241.

PEDERSEN, M., HANSEN, J.C., MULVAD, G., PEDERSEN, H.S., GREGERSEN, M. \& DANSCHER, G., 1999, Mercury accumulation in brains from populations exposed to high and low dietary levels of methyl mercury. Int.. J. Circumpolar Health., 58: 96-107.

RODIER, P.M., KATES, B. \& SIMONS, R., 1988, Mercury localization in mouse kidney over time: Autoradiography versus silver staining. Toxicol Appl Pharmacol., 257:235-245.

STOLENBERG, M. \& DANSCHER, G., 2000, Histochemical differentiation of autometallographic traceable metals $(\mathrm{Au}$, $\mathrm{Ag}, \mathrm{Hg}, \mathrm{Bi}, \mathrm{Zn}$ ): protocols for chemical removal of separate autometallographic metal clusters in Epon sections. Histochem. J., 32: 645-652.

VIARENGO, A., PONZANO, E., DONDERO, F. \& FABBRIH, F., 1997, A Simple Spectrophotometric Method for Metallothionein Evaluation in Marine Organisms: an Application to Mediterranean and Antarctic Molluscs. Mar. Environ. Res., 44: 69-84.doi:10.1016/S0140-1136(96)00103-1.

VILLEGAS, J., MARTINEZ, R., ANDRES, A. \& CRESPO. D., 1999, Accumulation of mercury in neurosecretory neurons of mice after long-term exposure to oral mercuric chloride. Neurosci. Lett., 271: 93-96.doi :10.1016/S0304(99)00529-7.

YOSHIDA, M., SATOH, M., YASUTAKE, A., SHIMADA, A., SUMI, Y.\& TOHYAMA, C., 1999, Distribution and retention of mercury in metallothionein-null mice after exposure to mercury vapor. Toxicology., 139:129-36.

ZALUPS, R.K., 1993, Early aspects of the intrarenal distribution of mercury after the intravenous administration of mercuric chloride. Toxicology., 79:215-228.

ZALUPS, R.K., 1996, Enhanced renal outer medullary uptake of mercury associated with uninephrectomy: Implication of a luminal mechanism. J Toxicol. Environ. Health., 50:173-194.

ZALUPS, R.K., BARFUSS, D.W. \& LASH, L.H., 1999 Effects of biliary ligation and modulation of GSH-status on the renal and hepatic disposition of inorganic mercury in rats. Toxicologist., 48:330-331.

ZALUPS, R.K., 2000, Molecular interactions with mercury in the kidney. Pharmacol. Rev., 52: 113-143. 